\title{
頸部転移巣より疑われた甲状腺オカルト癌例
}

\author{
堀龍介・田邊 牧人*・扇田 秀章

\section{A Case of Occult Thyroid Carcinoma Revealed by Cervical Lymph Node Metastasis}

\author{
Ryusuke Hori and Hideaki Ogita \\ (Kyoto University) \\ Makito Tanabe \\ (Nishi-Kobe Medical Center)
}

\begin{abstract}
A 26-year-old man visited our hospital with right neck swelling, which was initially diagnosed as a lateral cervical cyst. After follow up for approximately 5.5 years, the right neck swelling was diagnosed as cervical lymph node metastasis of thyroid papillary carcinoma on extirpation of the cyst. An additional operation, right lobectomy of the thyroid grand with unilateral neck dissection, was performed, but pathologically, no carcinoma was detected in the specimen. It was suggested that the carcinoma was missed because it was present between sections of the specimen. Finally we diagnosed the case as occult thyroid carcinoma.
\end{abstract}

There was no evidence of recurrence a year after surgery. The case is being closely followed up.

Key words : thyroid carcinoma, occult carcinoma, cystic metastasis

はじめに

甲状腺癌のなかで, 諸臓器転移巣による臨床症状が先 行するため, 原発巣を検索したが発見されず，その後そ れらの原発巣として甲状腺癌が発見された症例をオカル 卜癌という1）が，治療法は一定した見解を得ない，今回 われわれはオカルト癌と考えられた症例を経験し, 若干 の文献的考察を加え報告する.

\section{症例}

症例 : 26 歳, 男性.

主訴：右頸部腫脹.

家族歷・既往症：特記すべきことなし.

現病歴: 平成 11 年 1 月右頸部腫脹自覚し, 2 月当科受 診. 右胸鎖乳突筋後方に約 $3 \mathrm{~cm}$ 大, 弾性硬の腫瘤を触れ
た.

検査所見: 初診時に施行した頸部超音波検查（図 1) で は右側頸部に $1.5 \times 1.8 \times 1.0 \mathrm{~cm}$ 大，内部低エコーの囊 胞性腫瘤を認めた。囊胞壁の一部には不均一な部分も認 めた．悪性腫瘍の頸部転移の可能性も考え，囊胞性腫瘤 を穿刺したところ暗血性液体を吸引し, 細胞診では陰性 であった. 甲状腺超音波検查では右葉に小囊胞を散在性 に認めるが，明らかな腫瘤は認めなかった，以上より右 側頸囊胞を疑い経過観察としていた。 その後消退・腫脹 を繰り返し, 平成 16 年 3 月再々腫脹をきたしたため当科 受診した。頸部造影 CT を施行（図 2) し，右胸鎖乳突 筋内側・右内頸静脈背側に $2.2 \times 1.1 \mathrm{~cm}$ 大の境界明膫な 囊胞性腫瘤を認め, 囊胞壁の一部に造影効果を有する充 実性の結節を認めたが，甲状腺には腫瘍性病変を認めな

京都大学大学院医学研究科耳鼻咽喉科 - 頭頸部外科感鸴運動系外科学講座

*西神戸医療センター耳鼻咽喉科 

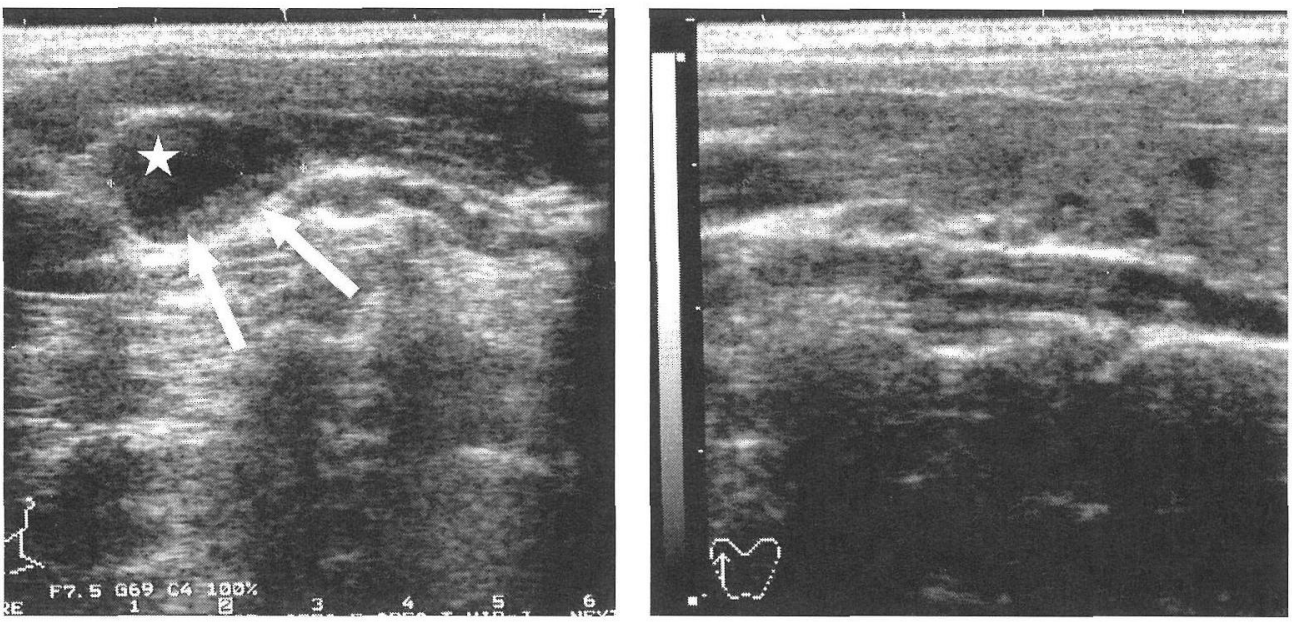

図 1 初診時頸部超音波検查所見（左：右側頸部，右：甲状腺右葉）

右側頸部に $1.5 \times 1.8 \times 1.0 \mathrm{~cm}$ 大の内部低エコーの囊胞性腫瘤を認める（星印）。囊胞壁の一部に不均一な部分を認めた（矢印）。 甲状腺右葉には明らかな腫瘤を認めない。

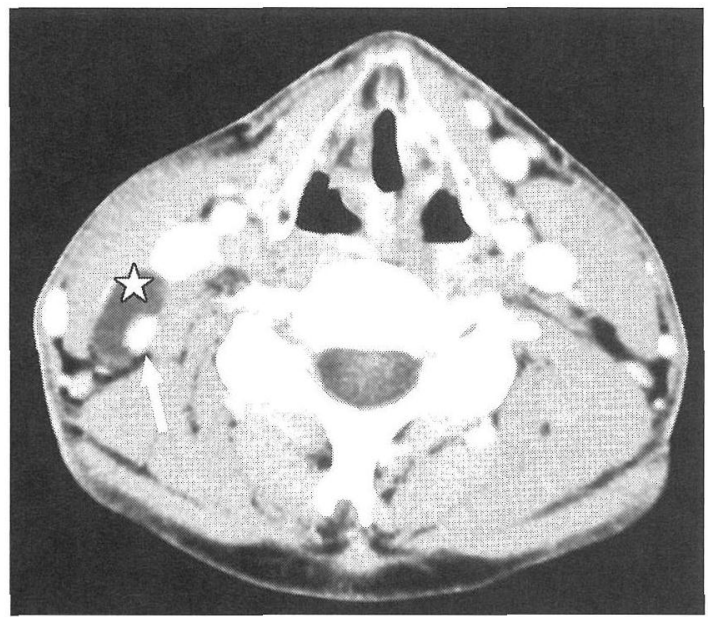

図 2 頸部造影 CT 所見

右胸鎖乳突筋内側・右内頸静脈背側に $2.2 \times 1.1 \mathrm{~cm}$ 大の 境界明膫な囊胞性腫瘤を認める（星印）。囊胞壁の一部に 造影効果を有する充実性の結節を認める (矢印)。

かった。

以上の所見から側頸囊胞を含めた頸部囊胞性腫瘍を 疑つた。

治療経過：平成 16 年 8 月 31 日右頸部腫瘍摘出術施行 した。胸鎖乳突筋外側縁を剥離すると囊胞状腫瘍が露出 した。腫瘍前方の内頸静脈および副神経を確認保存し, 腫瘍を周囲から剥離し摘出した。周囲と軽度癒着を認め たが明らかな浸潤は認められず，甲状腺との連続性はな

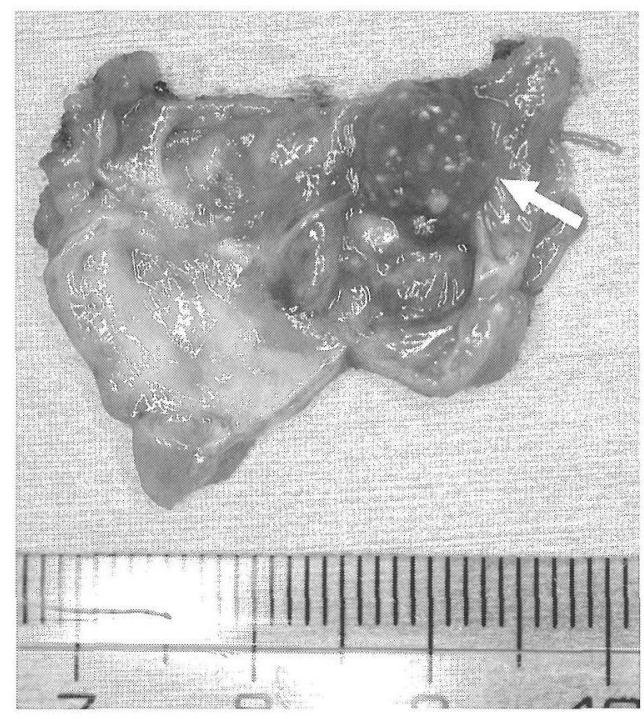

図 3 右頸部腫瘍の摘出標本

腫瘍は囊胞状で $2 \times 1.5 \mathrm{~cm}$ 大，内部に透明な液体を認め た。囊胞壁に $1.2 \times 0.7 \mathrm{~cm}$ 大の赤褐色充実性で軟らかい 腫瘤を認めた (矢印)。

かった。

腫瘍は囊胞状で $2 \times 1.5 \mathrm{~cm}$ 大，内部に透明な液体を認 めた。囊胞壁に $1.2 \times 0.7 \mathrm{~cm}$ 大，赤褐色充実性で軟らか い腫瘤を認めた (図 3). 病理組織学的に腫瘤は乳頭状の 増生を示す組織がみられ，核質はスリガラス状で，核溝・ 核内封入体がみられた（図 4)。霝胞壁内あるいは周囲に 


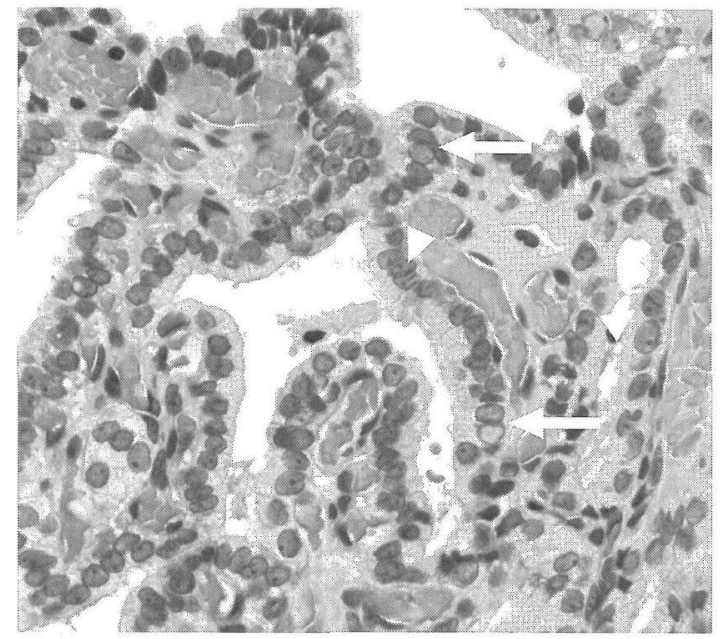

図 4 右頸部腫瘍隆起部の病理所見 (HE 染色, 40 倍) 乳頭状の增生を示す組織がタられ，核質はスリガラス状 であり，核溝（矢頭）・核内封入体（矢印）がみられる。

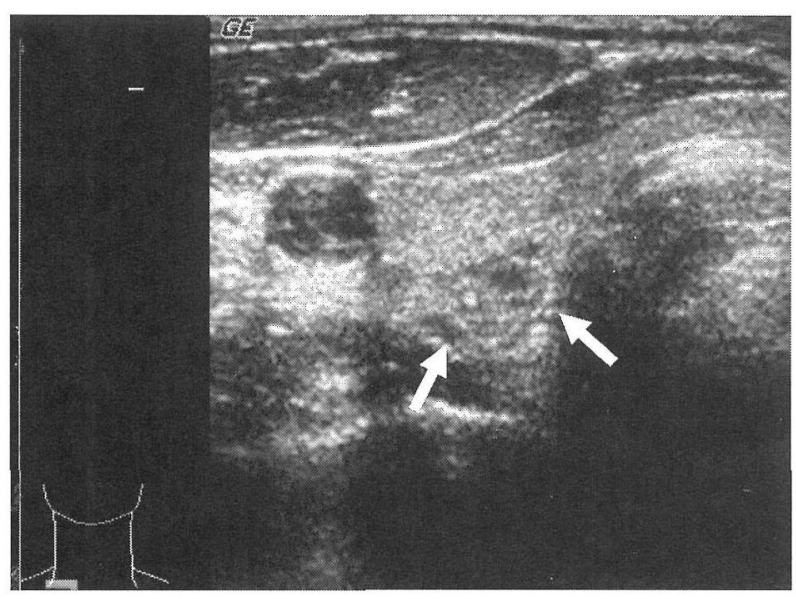

図 5 甲状腺超音波検查所見 右葉下極に $1 \mathrm{~cm}$ 以下の小囊胞の集簇を認める (矢印).

はリンパ組織がみられた。

以上の所見から摘出した右頸部腫瘍は甲状腺乳頭癌の リンパ節転移と診断した。

原発栄発見のため甲状腺の検索を行った。タリウムシ ンチグラム，テクネシウムシンチグラムを施行したとこ ろ優位な集積は認めなかっった。甲状腺超音波検査では甲 状腺右葉下極に $1 \mathrm{~cm}$ 以下の小囊胞の集簇を認めた（図 5)、穿刺吸引細胞診を行ったところ陰性であったが，こ 机らの所見から甲状腺右葉の小囊胞集簇が原発である可 能性を疑った。
平成 17 年 10 月 14 日甲状腺右葉峡部切除術, 右保存的 頸部郭清術（D2a 郭清）を施行した。甲状腺右葉下極に は肉眼上および触診上明らかな腫瘍は認めなかった。右 気管傍リンパ節・上内深頸リンパ節に $1 \sim 2 \mathrm{~cm}$ 大のリン パ節を数個認めた。病理組織学的には甲状腺右葉, 峡部 をスライス間約 $3 \sim 4 \mathrm{~mm}$ の連続切片にて検索したが乳 頭癌は認められず，リンパ節にも転移を認めなかった。 術後約 1 年現在, 再発を認めない。

\section{考察}

甲状腺オカルト癌の頻度は全甲状腺癌の $1.8 \sim 4.8 \%$ で,そのほとんどが乳頭癌であり最大径 $1 \mathrm{~cm}$ 以下の微小 癌で2) 4), 微小癌発見動機の $19 \%{ }^{3)}$ を占める。年齢は $11 \sim 77$ 歳2) 4) で，男女比は約 $1: 1^{2) 3)}$ であり通常の甲 状腺癌より男性の割合が多い。

甲状腺オカルト癌を初診時から診断することは非常に 難しく, 頸部リンパ節の炎症性病変, 側頸囊胞, 原発不 明癌の頸部リンパ節転移などとしか診断できないことが 多(2)3).甲状腺超音波検査では直径数 $\mathrm{mm}$ 以下の小さな 腫瘤でも検出できるとされているが5)，本症例を含めて 原発巣の検出は必ずしも容易ではない。千及和ら ${ }^{3)}$ や篠 原ら 6）も超音波検査にて原発巣の検出が不可能であった 症例を報告しており，実際の診断は穿刺吸引細胞診・生 検・術中迅速病理にて診断されることが多い。また甲状 腺乳頭癌が頸部リンパ節転移をきたすことはよく経験す るが，乳頭癌は囊胞状構造をきたしやすく，この性質は 転移巣においても同様の傾向を示すとされている7). 本 症例のように霓胞を呈した頸部リンパ節転移が発見の契 機となったオカルト甲状腺癌症例は，涉猟しえた限り本 邦 6 例2)46)8）しかなく比較的まれである。さらには初診 時に行った頸部腫瘍からの細胞診が陰性であったため最 終的に甲状腺癌と診断するのに苦慮した。このことから 頸部腫脹を主訴に来院した症例では，たとえ甲状腺など に腫瘤を認めなかったとしても，甲状腺癌をはじめとし た悪性腫瘍の転移の可能性が否定できないため頸部腫瘍 摘出術を強く勧めるべきであると思われる。

治療法は手術治療が主体である。郭清範囲は通常の甲 状腺癌と同様, 保存的頸部郭清術が必要と思われる。し かし甲状腺切除範囲については議論が分かれている。甲 状腺オカルト癌では臨床癌より腺内転移が高い上いう 報告がある。佐々木ら ${ }^{3)}$ は 19 例中 7 例 $(37 \%)$ ，千々和 ら 
報告している．腺内転移率が高いことを考慮すると甲状 腺全摘術をした方が安全である。しかし，オカルト癌は ほとんどの場合, 微小癌であり, 微小癌そのものの予後 がよいこと9) や，微小癌の増殖速度は遅くその約 $2 \%$ し か臨床癌に移行しないこと ${ }^{10)}$, 微小転移巣があっても予 後には影響しないこと年)より, すべての症例に全摘出術 を行うことは QOL の面からも望ましいとはいえない. よって転移側の片葉切除を行った後に, 摘出標本の連続 切片を検索することで腺内転移が確認できれば残葉切除 を追加する方針も挙げられる．本症例では当初は右葉の 病変が原発と考光，甲状腺乳頭癌が予後良好で若年でも あることからむやみに拡大手術をすべきでないと考え， 甲状腺右葉峡部切除・右保存的頸部郭清術という術式を 選択した。摘出標本の連続切片にて甲状腺右葉には癌を 発見できなかったが，可能性としては癌が標本の割面間 に隠机たか, 甲状腺左葉内に微小な原発巣があると考え られた。過去にも佐々木ら ${ }^{2)}$ は 19 例中 3 例（16\%），田 中ら ${ }^{11)}$ は 4 例中 2 例 $(50 \%)$ に原発巣を発見することが できなかったと報告している。結果的に原発巣は不明で あったため, 今後厳重に観察していく必要がある.

\section{まとめ}

1）頸部転移巣より発見された甲状腺オカルト癌の1例 を経験した。

2）結果的に原発巣は不明であったため,今後厳重に観 察していく必要がある.

本論文の要旨は第 151 回日耳鼻兵庫県地方部会 (平成 17 年 12 月 4 日，西宮市）にて口演した。

\section{参考文献}

1）甲状腺外科检討会編：外科・病理甲状腺癌取り扱い規約（第 5 版)． 3 頁，金原出版，東京，1995.

2）佐々木純，栗原英夫，谷村清明，他：オカルト甲状腺癌 19 例の経験. 内分泌外科 $21: 39 \sim 45,2004$.

3）千久和圭一，伊豆丸慎介，豊住康夫，他：転移リンパ節か ら判明した甲状腺オカルト癌. 耳鼻臨床 $94: 639 \sim 643$, 2001.

4）千賀 脩，宮川 信，疋田仁志，他：頸部リンパ節転移よ り発見された甲状腺不顕性癌の診断と治療。癌の臨 38 ： $1444 \sim 1450,1992$.

5）小西淳二：甲状腺. 甲状腺・頸部の超音波診断（小西淳二 編). $19 \sim 55$ 頁，金芳堂，京都， 1995.

6）篠原尚吾, 山本悦生, 田邊牧人, 他 : 頸部転移巣加ら発見 された甲状腺微小癌症例.耳鼻臨床 $92: 779 \sim 783 ， 1999$.

7) Tovi $\mathrm{F}$ and Zirkin $\mathrm{H}$ : Solitary lateral cervical cyst; Presenting symptom of papillary thyroid adenocarcinoma. Ann Otol Rhinol Laryngol $92: 521 \sim 524,1983$.

8）福田久也, 大浜寿博, 岡村泰彦, 他 : 頸部リンパ節転移が 囊胞を呈した甲状腺不顕性癌の 1 例. 川崎医会誌 13:78〜 82, 1987.

9）山田弘之, 藤田健一郎, 石田良治：甲状腺微小癌の診断と 治療 1. 癌の臨 $47: 421 \sim 426,2001$.

10）山下裕人, 野口志郎：甲状腺癌の病理学的特徴. 癌の臨 41 : $132 \sim 136,1995$.

11）田中 治, 松永 喬, 宮原 裕, 他：甲状腺微小癌の治療 成績. 耳鼻臨床 $85 ： 1125 \sim 1129 ， 1992$.

原稿受付: 平成 18 年 3 月 24 日

原稿採択：平成18年 6 月 16 日

別刷請求先 : 堀 龍介

̄606-8507 京都市左京区聖護院川原町54

京都大学大学院医学研究科耳鼻咽喉科・頭頸部外科感 覚運動系外科学講座 